\title{
CHARACTERIZING CUSTOMER EXPERIENCE MANAGEMENT IN BUSINESS
}

\section{MARKETS}

Lars Witell ${ }^{\mathrm{a}}$, Christian Kowalkowski ${ }^{\mathrm{b}}$, Helen Perks ${ }^{\mathrm{c}}$, Chris Raddats ${ }^{\mathrm{d}}$, Maria Schwabe ${ }^{\mathrm{e}}$, Ornella Benedettinif ${ }^{\mathrm{f}}$, Jamie Burton ${ }^{\mathrm{g}}$

aDepartment of Management and Engineering, Linköping University, lars.witell@liu.se, SE58183 Linköping, Sweden and CTF- Service Research Centre, Karlstad University, SE-651 88 Karlstad, Sweden

${ }^{\mathrm{b}}$ Department of Management and Engineering, Linköping University, christian.kowalkowski @ liu.se, SE-581 83 Linköping, Sweden and Hanken School of Economics, Department of Marketing, CERS —Centre for Relationship Marketing and Service Management, 00101 Helsinki, Finland

${ }^{\mathrm{c}}$ Nottingham University Business School, Jubilee campus, University of Nottingham, Nottingham, NG8 1BB, United Kingdom. helen.perks@nottingham.ac.uk

${ }^{\mathrm{d}}$ Management School, University of Liverpool, Liverpool L69 7ZH, United Kingdom. c.raddats@liverpool.ac.uk

${ }^{\text {e}}$ School of Economics and Business Administration, Friedrich-Schiller-University of Jena, maria.schwabe@uni-jena.de, 07743 Jena, Germany

fDepartment of Mechanics, Mathematics and Management, Polytechnic University of Bari, ornella.benedettini@poliba.it., Viale Japigia 182, Bari, Italy

${ }^{\mathrm{g}}$ Alliance Manchester Business School, University of Manchester, Manchester, M15 6PB, United Kingdom. jamie.burton@manchester.ac.uk

This is a pre-print (non-publisher's document). Please cite the published article:

Witell, Lars., Christian Kowalkowski, Helen Perks, Chris Raddats, Maria Schwabe, Ornella Benedettini and Jamie Burton. (forthcoming). "Characterizing customer experience management in business markets", Journal of Business Research. 


\title{
CHARACTERIZING CUSTOMER EXPERIENCE MANAGEMENT IN BUSINESS
}

\section{MARKETS}

\begin{abstract}
Managing the customer experience has become a top priority for marketing managers and researchers. Research on customer management experience (CEM) has traditionally adopted a customer's viewpoint. Few studies have explicitly embraced an organizational perspective, and existing research focuses mainly on business-to-consumer settings. The present study espouses the utility of CEM in business-to-business (B2B) settings on the grounds that interactions in B2B contexts are also "experienced". It explains how B2B firms can design and manage the customer experience to influence the customer at different touchpoints. The paper develops a comprehensive framework that characterizes CEM in B2B. The paper articulates key challenges for B2B CEM; relationship expectations (mismatches in customer relationships, siloed customer experiences); actor interaction issues (mismatches across the customer's journey, lack of touchpoint control); and temporal challenges (dynamics of the customer experience). The paper draws out the theoretical implications and develops managerial implications for B2B firms.
\end{abstract}

Keywords: customer experience management, customer journey, market strategy, B2B, touchpoint

\subsection{Introduction}


Customer experience is the capability to drive profits and growth

Chief Digital Officer, global truck manufacturer

The volume of research on customer experience has increased exponentially over the past decade, ${ }^{1}$ extending beyond retailing to public sector and business-to-business (B2B) settings. Lemon and Verhoef (2016) traced this development back to 1960s' research on customer satisfaction, relationship marketing, and customer engagement and the development of buyer behavior process models. Customer experience can be defined as "a multidimensional construct focusing on a customer's cognitive, emotional, behavioral, sensorial, and social responses" to a firm's offerings and actions (Lemon \& Verhoef, 2016, p. 71). In general, customer experience is considered internal to the customer (Heinonen et al., 2010), subjective, and not fully controlled by the supplier (Kranzbühler et al., 2018; Verhoef et al., 2009).

The growth in customer experience research reflects suppliers' focus on (co)creating and managing that experience (Patrício et al., 2008). Firms increasingly look to customer experience management (CEM) as a key source of competitive advantage (Pine \& Gilmore, 1998), and especially as a strategic response to commoditization. The latter occurs when competitors offer ever more homogenous goods and services to price-sensitive customers in markets where switching costs are low (Rangan \& Bowman, 1992). As offerings become commoditized, product leadership and operational excellence become less influential, while intimacy becomes critical for customer satisfaction and competitive advantage (Reimann et al., 2010). To better meet customers' specific needs, firms must then actively seek to design memorable customer experiences (Harby, 2018; Pine \& Gilmore, 1998).

\footnotetext{
${ }^{1}$ A Google Scholar search for "customer experience" <www.scholar.google.co.uk/scholar?q=customer+experience\&hl=en\&as sdt=0\%2C5\&as ylo=2009\&as yhi=2019> (06/10/2019) returned approximately 1,690,000 publications for the period 1800-2009, which roughly equalled the number of publications in the last 10 years (2009-2019).
} 
Most of the customer experience research to date has adopted a consumer perspective (e.g., Hirschman \& Holbrook, 1982; Homburg et al., 2017; Pine \& Gilmore, 1998). Few studies have explicitly taken an organizational perspective, and there is also a lack of research on CEM in B2B settings (Zolkiewski et al., 2017). This is surprising in light of the importance of interpersonal interaction in business markets (Aarikka-Stenroos \& Jaakkola, 2012) and the long-term orientation of many B2B relationships (Håkansson et al., 2009; Tuli et al., 2007). In B2B settings, offerings are generally more complex (Nordin \& Kowalkowski, 2010), as are interactions between the actors involved (Holmlund, 2004). Not only are multiple, different business actors participating but, since the customer is an organizational entity, several actors generally exist within the customer firm. Each actor plays a different role (such as buyer, decision-maker, user) (Webster \& Wind, 1972), interacting in different ways (Mikolon et al., 2015) and at different stages of the customer journey. It follows that accepted conceptualizations of CEM based on consumer research, such as the notion of a singular journey, are overly simplistic (Zolkiewski et al., 2017).

We contend that these consumer-based notions fail to account for the way firms manage customer experiences in business markets. The current article seeks to address this research gap by developing a comprehensive CEM framework that focuses on B2B settings. To that end, we explore how B2B firms can design and manage the customer experience to influence the customer at different touchpoints. The multidimensional framework addresses two key issues: relationship control and the customer entity. We go on to identify and discuss five key challenges for B2B CEM. These relate to relationship expectations (mismatches in customer relationships $(\mathrm{C} 1)$ and siloed customer experiences $(\mathrm{C} 2)$ ); actor interactions (mismatches across the customer's journey (C3) and lack of touchpoint control (C4)); and temporal challenges (the dynamics of customer experiences (C5)). Based on our findings, we articulate key theoretical and managerial implications for CEM in business markets. 


\subsection{Customer experience management in B2B markets}

Traditionally, B2B contexts are seen to entail rational and economic-based decision making (Hadjikhani \& LaPlaca, 2013). Contrary to this view, we contend that interactions between employees mean that the experiences of business customers are likely to resemble customer experiences in business-to-consumer (B2C) contexts. Employees' experiences, when interacting with other employees, as well as with physical equipment, software, and services, are likely to include cognitive, emotional, behavioral, sensory, and social components (Lemon \& Verhoef, 2016). Interactions can take place among individuals (operating at differing hierarchical levels) or collectives (such as functional units). Individual and collective experience interact, as individual perceptions can support collective perceptions, and vice versa. In addition, B2B interactions may involve a wide range of front-office and back-office actors, making it more difficult to understand the customer experience (Zolkiewski et al., 2017). It seems likely that these components of the customer experience will vary in importance across individuals and functional units.

Existing research on CEM offers several conceptual frameworks and models that suggest how B2C firms can more effectively manage interactions with customers. Among these, Kranzbühler et al. (2018) proposed that an organizational perspective of customer experience should (1) identify ways of designing and managing interactions with customers (see also Patrício et al., 2008) and (2) analyze how employees and the servicescape influence customer experiences (see also Bitner, 1990). Verhoef et al. (2009) viewed CEM, from an organizational perspective, as a strategy for shaping the customer experience to create value for both the customer and the firm. However, the B2B customer experience cannot be measured in the same way as the B2C customer experience (Zolkiewski et al., 2017), and this presents certain challenges. In B2B contexts, the emphasis is on understanding and delivering 
value in use (Eggert et al., 2018; Lemke et al., 2011). As most B2B offerings are complex and networked, value encompasses the capabilities of supplier, partner, and customer organizations, as well as how the offering is used in the customer organization (Forkmann et al., 2017).

Table 1 sets out extant research in terms of conceptualizations of CEM. It shows that most research is conceptual; the major setting is retailing; and only a few contributions study B2B CEM. Notable exceptions include Zolkiewski et al. (2017) who provide a conceptual framework for CEM focusing on outcomes for the customer, while McColl-Kennedy et al. (2019) use text analysis to unravel B2B firms' learnings from text mining and big data. Building on these pioneering initiatives, further research is required to develop a comprehensive framework for B2B CEM that can help firms address multiple interactions with different employees in different positions and representing diverse functional units at the customer site. Based on existing research and the authors'own studies of employee-customer interactions in B2B settings, this article develops and discusses two critical characteristics for CEM in business markets; managing relationship types and managing control of touchpoints within a network of actors. These characteristics underpin the development of a comprehensive framework for B2B CEM. Given the multi-faceted nature of customer experience in B2B settings articulated above, we examine implications and unravel challenges that supplier organizations face in managing the customer experience.

--- Insert Table 1 ---

\subsection{Managing relationship types}

A supplier needs to build portfolios of customer relationships to increase its return on relationships (Zolkiewski \& Turnbull, 2002). Traits of the buyer-seller relationship, spanning from transactional to relational exchanges, will to a large degree influence the customer experience (Homburg et al., 2017). Transactional exchanges involve single, short-term 
exchange events encompassing a distinct beginning and end. They frequently depend on market control and automated purchasing (Day, 2000), and are completed when the customer has received the product and has paid for it (Johnson \& Selnes, 2004). In contrast, relational exchanges involve events linked together over time and represent an ongoing process of exchanges which trace back to previous interactions (Gundlach \& Murphy, 1993). Compared with transactional exchanges, long-term relationships rely more on administrative and bureaucratic control, and collaboration between suppliers and customers or channel partners (Day, 2000). In business relationships, different forms of cooperation exist, by which both parties co-ordinate their activities to generate outcomes with expected reciprocity over time (Anderson, 1994).

\subsection{Managing control of touchpoints in a network of actors}

Touchpoints in a B2B context encompass all verbal and nonverbal incidents that a business customer experiences, either consciously or unconsciously, related to a supplier firm (Homburg et al., 2017). Thus, touchpoints include various forms of interaction involving different actors. Those actors may come from the supplier firm, the customer firm, or partner firms (e.g., service firms providing outsourced services), or they may be embedded in the wider associated ecosystem (Zolkiewski et al., 2017). Within each firm, touchpoints involve different functional and organizational units, as well as individuals operating at diverse hierarchical levels. For example, senior managers in a supplier firm (hierarchical level) may negotiate a long-term contract with the customer firm's procurement department (functional level). In this case, the interactions involve individual users and managers (individual level) and collective entities (functional level).

Additional time-based complexity arises. As different actors (acting both individually and on behalf of a functional unit) engage in different touchpoints at different stages of the customer journey, no single individual actor is necessarily involved throughout the entire 
customer journey. Models of the customer journey tend to be product- or brand-centric, with clear pre-purchase, purchase, and post-purchase stages (Lemon \& Verhoef, 2016).

Alternatively, they may be service-centric, involving stages such as pre-core, core, and postcore service encounters (Voorhees et al., 2017). In contrast, the B2B customer journey can be conceptualized as a set of relational processes to meet the customer's business needs. The literature on advanced services and solutions identifies four distinct but interrelated stages: pre-bid engagement, negotiation, implementation, and operations (Brady et al., 2005; Tuli et al., 2007). Each stage entails different types of touchpoints involving the firm, customer, partner firms, or other actors from the wider ecosystem.

According to Lemon and Verhoef (2016), CEM requires a multidisciplinary approach in which multiple functions and network partners cooperate to manage the customer experience. Managing touchpoints within such a network of actors is a critical characteristic of CEM in B2B settings. This suggests that the customer experience should be designed across different touchpoints, which can reside within or outside the firm. For example, the focal company's partners need to understand how they contribute to the customer experience (Meyer \& Schwager, 2007). As an illustration, lift-truck manufacturer Raymond operates through an extensive North American network of dealers. This means that it does not own the serviceprovision touchpoint with customers (Kowalkowski \& Ulaga, 2017), and service provision is built on relationships between actors in business networks with distinct structures that are created intentionally (Kowalkowski et al., 2013). Thus, the success of CEM relies on the ability to handle business relationships, both with partners and with customers.

This diversity of actors and touchpoints raises a critical question for touchpoint control: Who exerts the greatest influence on the customer experience? Here, we differentiate between touchpoints controlled by the supplier, customer, partner, or actors from the wider ecosystem. For example, customers hold the supplier less responsible when the touchpoint carries a 
partner's brand and is under their control (Kranzbühler, Kleijnen, \& Verlegh, 2018). When performed under a partner's brand name, a touchpoint is no longer associated with the focal supplier but rather with the partner. However, this carries some risk, as the supplier does not control the touchpoint and so has less influence over the customer experience (Kowalkowski \& Ulaga, 2017).

An organization controls a touchpoint if it is the principal entity that can determine and influence what actors will do. The level of control is defined as the degree to which one party believes it can ensure the other actor's desired behavior (Das \& Teng, 1998). From a CEM perspective, a supplier firm with stronger control of a touchpoint can design and manage the customer experience to a greater extent than a firm with less touchpoint control. Table 2 summarizes touchpoint activities controlled by different actors at various stages of the customer journey.

--- Insert Table 2 ---

\subsection{A framework for customer experience management in B2B settings}

Building on the above characterizations, we developed a framework for CEM based on four dimensions. Two of these (type of business relationship and control of touchpoints) build on the characteristics discussed above and relate to relationship control; the other two (function and hierarchical level and stage of the customer journey) relate to customer entity.

Regarding relationship control dimensions, type of business relationship refers to whether the relationship is transactional or relational. Zolkiewski (2004) noted that a firm can

only generate and maintain a finite number of collaborative and relational exchanges; if a firm has a large customer base, more of its relationships are likely to be transactional. For relational customers, the goal must be to provide appropriate experiences at each touchpoint. However, a firm with a large portfolio of transactional relationships may need to prioritize multiple possible customer touchpoints dependent upon which are central to the customer 
experience (Johnson \& Selnes, 2004). The second dimension concerns the holder of touchpoint control (Homburg et al., 2017). Touchpoints can be controlled by the customer, supplier, partner or by external actors in the wider ecosystem. This dimension is key as it determines who controls those touchpoints where the customer experience takes place.

The two further dimensions relate to customer entity. These are outside the control of the supplier, but are critical elements to take account of in the management of the customer experience. Thus the third dimension concerns function and hierarchical level of the customer. This dimension implies that the customer experience needs to be managed differently dependent on the organizational design of the customer; that is, whether the customer has well-developed internal and external service capabilities and where they reside within its organization (Forkmann et al., 2017). The fourth dimension relates to the stage of the customer journey (Brady et al., 2005; Tuli et al., 2007), which concerns the processes a customer goes through, across all stages and touchpoints, that make up the customer experience. Dividing the customer experience into stages enables its management at the different touchpoints, although only some of these touchpoints are under the supplier's control.

\subsection{Key Challenges in B2B Customer Experience Management}

Based on the framework in Figure 1, five key challenges for B2B CEM are identified. Two challenges relate to relationship expectations, namely mismatches in business relationships (C1) and siloed customer experiences (C2). Two further challenges relate to actor interaction issues, namely mismatches across the customer's journey (C3) and lack of touchpoint control (C4). A final fifth temporal challenge relates to the dynamics of the customer experience (C5). Table 3 provides an overview of these challenges and their implications for B2B CEM. In the following sections, we discuss these challenges in detail. 


\subsection{Relationship Expectation Challenges}

\subsubsection{Mismatches in customer relationships (C1)}

B2B relationships are often based on mutual relational exchanges, in which supplier and customer work together to create new forms of value (Eggert et al., 2018). These often move from transactional to relational exchange (Johnson \& Selnes, 2004). However, mismatches in business relationships can occur with regard to the state of the relationship (relational or transactional) or divergences around what constitutes an "excellent customer experience".

Mismatches may ensue if suppliers fail to differentiate between the diverse value and relational orientations of different customers, leading to the development of unprofitable customer relationships by such suppliers (Zablah et al., 2005). As an example, a customer might control the touchpoints and want a transactional exchange, but the supplier desires a more relational business relationship. This mismatch can be illustrated through an example reported in the UK market, in which a large supermarket (customer) wants to oversee a large logistic firm (supplier). The customer micro-manages the supplier, thus diminishing its ability to control touchpoints and develop the best way (from the supplier's perspective) to provide superior customer experience. This can lead to an inability on the supplier's part to harness the best value internally, since it can be onerous to get diverse functions to work together for a common goal when they must constantly respond to transactional customer demands.

Conversely, a supplier aiming for efficiency and standardization for less profitable customers might seek a transactional relationship while the customer expects a relational business relationship, and expects the supplier to provide this. Oil and gas company Shell illustrate this point, as it has pulled back from customization for all buyers, avoiding costly service provision. This creates a standardization challenge, but provides agility when a customer wants ongoing relational exchanges and is willing to invest in them. Shell went 
through a process of reviewing the complexity of its offerings and degree of relational customization across its customer base, moving some customers to transaction-only offerings. In doing so, it lost several customers who wanted a relational customer experience, but that were not willing to pay what Shell demanded of them (Murphy et al., 2005). In reviewing its range of offerings, Shell switched to a portfolio approach for managing customer relationships (Johnson \& Selnes, 2004; Zolkiewski \& Turnbull, 2002), allocating customers to the most appropriate internal service provider within its organization, hoping that, over time, mismatches would be reduced through transparency with customers over cost structures.

In terms of defining "excellent customer experience", interpretations may differ among suppliers, partners (if involved), and customers. With greater openness and transparency over costs, the actors involved may be more likely to agree on an "appropriate customer experience" level, whereby both (or all) parties buy into a common understanding of the type of relational exchange. Fundamental mismatches may be more likely to arise when a power imbalance exists between actors (Zolkiewski et al., 2008), with the more powerful actor controlling the touchpoints and the resources needed to create the customer experience.

\subsubsection{Siloed customer experiences $(C 2)$}

Additional challenges embodied in the B2B customer experience lie in the varying expectations and perceptions between different individuals and organizational units in the customer organization, and in the siloed nature of consumption deriving from breaking the customer “experience chain" (Homburg et al., 2017). While B2B suppliers may have fewer customer relationships than $\mathrm{B} 2 \mathrm{C}$ firms, these present more complex management challenges because they include multiple contacts at differing levels and usually across multiple touchpoints (Hollyoake, 2009; Roy et al., 2019). In B2B contexts, the customer entity includes multiple actors representing various roles and departments at different individual, functional, and hierarchical 
levels (Andersson-Cederholm \& Gyimóthy, 2010; Burton et al., 2016; Cortez \& Johnston, 2017).

In a large customer organization in particular, if the central procurement function is reponsible for touchpoints with the supplier and purchases a new type of offering, local managers and users may be reluctant to change, oppose the decision, and even try to bypass the new arrangement. Kowalkowski (2011) uses the example of a customer having consolidated its supplier base for logistics services and signed a central agreement with a single supplier. While local entities within the customer firm may notice that transportation costs on their sites have actually increased, they may not recognize that total costs have actually decreased. Thus, to mitigate the risk of such siloed experiences, the supplier should should design multiple touchpoint opportunities with the customer to ensure holistic understanding of the customer experience, both localized and centralized.

Another example, from a manufacturer of paper machines may illustrate the siloed customer experience. The purchasing manager of a pulp and paper mill ordered a maintenance contract built on a profit-sharing mechanism with the supplier. The supplier was very successful in eliminating production problems and faulty equipment leading to a large increase in productivity. The production manager received a great customer experience, although the maintenance manager felt like the supplier had 'stepped on his toes', as he was the one who had to pay maintenance costs from his budget due to the profit-sharing contract. Thus, the siloed customer experience may result in 'push back' against the supplier, dependent on who is responsible for and controls the touchpoint in the customer organization - the production or maintenance manager.

It is also important to note that, in B2B settings, the customer experience is often shaped by a team (such as all those working in a purchasing department), while in B2C settings, the customer is more often than not a single individual (Pansari \& Kumar, 2017). Although the 
B2B customer experience can also be at the individual level (Macdonald et al., 2016), teams tend to create a "peer effect" (Mora Cortez \& Johnson, 2017). Here psychological and social factors inevitably influence the supplier-customer interaction, as the experiences of $\mathrm{B} 2 \mathrm{~B}$ customers may focus more on objective touch point effects and less on personal emotions (Pansari \& Kumar, 2017). While individuals and teams may assess their experiences primarily on the basis of supplier attributes, functional benefits, and key performance indicators (KPIs), failure to answer an email, respond to a phone call, or help an individual customer can result in a bad customer experience, with long-term effects on the business relationship.

\subsection{Actor Interaction Challenges}

\subsubsection{Mismatches across the customer journey (C3)}

Mismatches can appear at each stage of the customer journey. This is particularly apparent in a B2B setting due to the inclusion of partners in service provision and the involvement of a diversity of actors, within both the supplier and customer firms, at different stages of the customer journey. In addition, multiple customer journeys might take place concurrently as the customer procures a variety of offerings from the same supplier.

Actor involvement varies from stage to stage of the customer journey. This implies that touchpoints, which do not appear key in the overall organizational level journey, may become 'moments of truth' for individual actors. For example, pre-bid and negotiation stages involve buyers, senior managers, and board members, whose experiences and expectations are influenced by the availability of decision-making information. In contrast, the operations stage involves end users whose experiences and expectations are based on the quality and utility of the purchased product and/or services, as well as on interactions with the supplier's (or partner's) frontline service staff. In such circumstances, multiple actors participate in only one stage of the customer journey, with differing expectations regarding touchpoint experiences and design (Roy et al., 2019; Zolkiewski et al., 2017). 
During the pre-bid engagement stage, informal discussions between a customer and supplier (existing or potential) may take place to understand potential overlap between the customer's business needs and priorities and the supplier's capabilities, which may then lead the parties to jointly identify new value-creation opportunities (Biggemann et al., 2013). Potential mismatches at this stage include the supplier not understanding how to best engage with the customer organization, different degrees of formalization in information sharing between supplier and customer firms about needs and capabilities, and the need for and importance of trusting personal relationships, which may be particularly important in crosscultural business exchanges (Zaheer \& Zaheer, 2006). Furthermore, inadequate understanding of the customer's future business needs may lead to unrealistic expectations and thus mismatches in later stages of the customer journey.

During the negotiation stage, the customer specifies what needs to be bought, provides information about its operations and current needs through touchpoints at different actor levels, and selects the most suitable supplier (van Weele, 2002). One example of a potential mismatch here concerns investment in sales automation as opposed to a customer-focused salesforce and account management approach (Sheth \& Sharma, 2008). If transactional and of low value, many activities may be automated (e.g., information access, automated purchasing, reverse auctions), and touchpoints may be confined to operational and tactical levels, such as senior buyers and materials planners, and chosen from a set menu (Talwar et al., 2008). On the other hand, if the value proposition is of strategic importance, the customer may seek a tailored solution to solve a specific problem, where the value proposition is jointly developed with the customer. Finally, a common source of mismatch in the later stages is the practice of offering services free of charge in order to land a deal. This practice is common in many product firms and often creates internal tensions, leading to unrealistic customer expectations at later touchpoints (Kowalkowski \& Ulaga, 2017). 
Once contract terms are settled, the implementation stage commences (Biggemann et al., 2013). To facilitate effective deployment, so avoiding a mismatch between expectations and actual experience, the customer may brief the supplier about the political landscape inside the organization. Such information and guidance can help the supplier identify the most relevant touchpoints and stakeholders (Tuli et al., 2007) and navigate potential tensions between key actors (Burton et al., 2016). One potential challenge arises when actors at different levels within the customer firm differ in their willingness to accommodate a supplier's offerings (Burton et al., 2016). For example, a truck manufacturer might use telematics and big data to manage driver behavior, reduce insurance costs, and monitor and manage the overall condition of its trucks. While this value can be shared with its customer, the customer's employees, namely drivers and their union, may be unhappy with this monitoring system when actually implemented (Raddats et al., 2017). In this way, when the customer reaches the operations stage, the implemented system may improve the customer experience for one type of customer (managers) while worsening it for others (the drivers). The operations stage covers all activities that take place throughout the contractual period of the service offering or, in the case of product procurement, the product life cycle (Biggemann et al., 2013). This is typically the longest stage and may span several years or even decades (Brady et al., 2005). The more extensive and strategic the exchange, the greater the number of business functions and actors from different hierarchical levels that will typically be involved (Kowalkowski \& Ulaga, 2017). Potential mismatches can arise when moving to the operations stage or during it from any of the key challenges that we have identified.

\subsubsection{Lack of touchpoint control (C4)}

Mismatches can also arise when touchpoints are controlled by an actor other than the supplier. Partners and other external actors can create or influence interactions between customer and supplier (Kranzbühler et al., 2018; Lemke et al., 2011; Lemon \& Verhoef, 2016; Patrício et 
al., 2011). Partner-controlled touchpoints originate primarily by a decision by the supplier firm to task third parties to provide services to the customer. This may be because such arrangements offer certain advantages or because the supplier is unable to bypass a powerful intermediary (Nordin et al., 2013). In other instances, a customer may stipulate that the supplier must collaborate with one or more external firms. In many industries, the principal interface with customers is often a partner firm. The partner characteristics can often determine the supplier's success, for example whether partners are few and powerful—as for instance in the case of Caterpillar - or multiple, as in the case of John Deere, which in the US alone has over 2,000 dealerships (Kowalkowski \& Ulaga, 2017). As the supplier does not come into direct contact with the customer, the challenge is how best to monitor the quality of experiences provided through touchpoints, particularly during the operations stage (Wynstra et al., 2015). Van Iwaarden and van der Valk (2013) recommended process standardization and use of incentives to manage quality ex ante and to actively influence third parties' performance. While the customer may appreciate a relational approach, the supplier loses control of this touchpoint and cannot directly manage the customer experience. For some suppliers, the partner takes over the relationship for the long term; as a manager at a logistics provider observed, "It is two-and-a-half years since ABC's procurement (the main supplier) has been involved in some ongoing contracts." As a result of this mismatch, the customer may seek a business relationship with the partner rather than the supplier when the time comes to renew the contract.

Another key challenge for the supplier is deciding which touchpoints it will control and which should be partner-controlled. Wynstra et al. (2015) discuss a truck manufacturer outsourcing field maintenance on customers' trucks to third-party maintenance firms. The manufacturer may obtain diagnostic/availability data from customers, define maintenance activity, and schedule maintenance events to be executed by maintenance companies; or it 
may simply allocate customers to third-party maintenance companies at the outset, then leave it to these third parties to manage details of interactions at this touchpoint with customers. The latter strategy may be more attractive when the offering is limited to basic maintenance/warranty services, but less so when it is part of an extensive outsourced solution.

In addition to firm-controlled and partner-controlled touchpoints, the use of customercontrolled touchpoints highlights the customer's active role as a network actor. In general, customers participate actively in the co-creation of experiences in the operations stage of the customer journey (Bolton et al., 2018; Cortez \& Johnston, 2017; Zolkiewski et al., 2017); they may also participate in the touchpoint design process (Lemke et al., 2011; Lemon \& Verhoef, 2016). A critical issue arises when the customer uniquely defines and controls the touchpoint — for example, by virtue of its relationship power. When the customer controls touchpoints within a relational exchange, they call the shots and determine who plays what role. The supplier firm is expected to adapt their activities and processes accordingly, resulting in intense collaboration with the customer. Nevertheless, managing these touchpoints to create a satisfactory customer experience can be difficult because of the significant unilateral adaptation required to meet the customer's needs.

\subsection{Dynamics of the customer experience (C5)}

Touchpoint control and design can change over a relationship's duration. Homburg et al. (2017) emphasize that a static perspective is no longer adequate for customer experience design and management. In other words single touchpoints need to be developed and modified continuously based on contextual cues (Bolton et al., 2018). A supplier may design a relational touchpoint but may be forced to shift to a more transactional approach over time. Similarly, a customer may design touchpoints that are appropriate for a transactional exchange, but insufficient value-creation potential may prompt a shift toward relational exchange over time, influencing the design of key touchpoints for CEM. For example, 
Raddats et al. (2016) describe how a servitizing supplier in the defense sector had to adapt its offerings when the customer (which controlled the touchpoint) specified new requirements. The supplier had to switch its offering from military equipment and services to providing knowledge-based capabilities to support in-house services.

As firms move toward more extensive contractual agreements, relationships and touchpoints change. For example, when Michelin moved from selling tires to selling kilometers, new touchpoints were needed to manage the customer experience. The new value proposition required the development of closer relationships with partners, more training and support, and much closer monitoring and quality control of performance. This also involved negotiation with senior actors in customer organizations and new contractual arrangements (Renault et al., 2010). Incorporating partners in these new business models may threaten the manufacturer's role in designing the customer experience and touchpoints, and creating and claiming long-term customer value. In this sense, the development and evolution of a supplier's business model parallels the emerging challenge of dynamic allocation of touchpoints to other actors.

\subsection{Discussion}

\subsection{Theoretical Implications}

This paper presents a comprehensive B2B approach to customer experience and further develops the concept of CEM. The present research brings forward three main theoretical contributions.

First, in contrast to extant research focusing on B2C customer experience in a retail context (e.g. Grewal et al., 2009, Verhoef et al., 2009), this study is one of the first to consider customer experience in a B2B context. By taking a multiple actor perspective it is possible to unpick the multi-dimensional definitional construct of customer experience ( see Lemon \& Verhoef, 2016). We argue that while dimensions such as 'emotional, behavioral and sensorial 
responses' are more appropriate to individual actors, such as managers within the customer firm, 'cognitive responses' are more appropriate for functional units, such as the customer's purchasing department. It could also be argued that social responses are relevant at both individual and functional unit levels, as for example when a purchasing manager and department respond individually and collectively to interactions with other individuals and functional units within the customer firm. Equally, we see multiple, simultaneous customer journeys in a B2B context as customers often buy various offerings from the same supplier, in contrast to Lemon and Verhoef's (2016) view of single journeys in a B2C context. Finally, while it is acknowledged that customer experience is often outside the control of suppliers (Kranzbühler et al., 2018; Verhoef et al., 2009), the multiplicity of possible touchpoint controllers in the $\mathrm{B} 2 \mathrm{~B}$ customer journey makes it more complex than one in a B2C context.

Second, a conceptual framework for CEM is presented based on four dimensions: two relationship control dimensions: (1) the nature of the relationship and (2) touchpoint control and two customer entity dimensions: (3) function and hierarchy level and (4) stage of customer journey. Through the inclusion of touchpoints as a core characteristic, the research builds on previous conceptual frameworks, such as Homburg et al. (2017). The introduction of touchpoint control, however, enables us to provide a more comprehensive theoretical conceptualization of CEM. Previous B2B CEM frameworks use a narrower focus, such as Zolkiewski et al. (2017) focusing on outcome-based measures. In addition, the framework includes customer entity as a core characteristic that is not in control of the supplier. This implies that there are factors that the supplier cannot directly influence, increasing and acknowledging the complexity of CEM in business markets. Thus, the present framework provides the most complete conceptualization of B2B CEM to date.

Third, the study identifies five key challenges, aligned to the four B2B CEM dimensions. These comprise; relationship expectations (mismatches in customer 
relationships, siloed customer experiences); actor interaction issues (mismatches across the customer's journey, lack of touchpoint control); and temporal challenges (dynamics of the customer experience). Several key challenges are identified which are unique to the B2B context; the number of customer actors perceiving the experience, either individually or collectively; the inter- and intra-organizational nature of customer experience; realization and tensions over touchpoint control and differing actor preferences for relationship type. Thus, the paper is the first to systematically align the key challenges of B2B CEM to its main characteristics.

\subsection{Managerial Implications}

For companies operating in B2B markets, CEM is potentially a key differentiator. In particular, managers should categorize customers according to the nature and potential of the relationship, as implied by the type of relationship dimension identified in the extant study. For relational relationships, suppliers should ensure provision of excellent customer experiences across all touchpoints. For most transactional relationships, managers should prioritize the most important touchpoints. It may be a priority, for example, to facilitate seamless access to a supplier's website and enterprise system. Furthermore, managers need to take account of the specific expectations of each individual at diverse hierarchical and functional levels within the customer organization, leading to the design of different and tailored experiences. For example, senior managers may value hedonic and informational experiences with account managers and peers at supplier organizations, while more junior purchasing executives may simply require utilitarian and standardized experiences when dealing with suppliers.

In relation to touchpoint control, managers need to be aware of who is controlling particular touchpoints as part of CEM. As some (but rarely all) touchpoints may be suppliercontrolled, managers need to understand which touchpoints their firm can control and which 
are more appropriately controlled by the customer or by a partner. For example, suppliers may prioritize the use of account managers as part of a customer management process to facilitate relational exchanges. Equally, if the supplying firm works with partners that are central to the customer experience at certain touchpoints, they should seek to minimize potential tensions or conflicts. Unless properly trained and managed, partners may not provide services that meet customer expectations, which could damage the supplier's brand. However, partners who work closely with suppliers can elicit advantages for both parties.

In terms of the stage of the customer journey, different experiences are likely required at each stage. For example, at the pre-bid engagement stage suppliers may need to sell their capabilities and vision for the customer's business, whereas at the operations stage the focus shifts to delivering consistent performance, such as provision of timely and reliable technical support.

Overall, the study suggests that managers should ensure they are able to address the challenges of managing CEM. Firstly, for mismatches in customer relationships, suppliers must align their expectations with those of customers vis a vis the type of relationship (relational or transactional) that either currently exists or is sought. On the one hand, the relational customer should not expectto receive superiore customer experiences than are actually delivered. On the other hand, suppliers should not over-commit to delivering experiences for the transactional customer, which could lead to unprofitable business. Equally, managers should endeavor to establish a common understanding of what constitutes an excellent customer experience between suppliers, customers and partners. Second, in terms of siloed customer experiences, managers need to appreciate that customers, particularly large organizations, may operate in 'silos', with individuals (at different hierarchical levels) and functional units sometimes failing to share information or even having conflicting interests. Thus, suppliers need to invest in communication activities to elicit the objectives of each 
individual and functional unit to ensure they invest greatest efforts in managing the most important touchpoints for the most critical parties. Third, due to lack of touchpoint control, suppliers will not control every touchpoint, with partners and customers sometimes taking this role. Managers, therefore, need to design the customer experience to take account of this issue. Where a partner interacts with the customer, for example, providing the partner with clear expectations and standardized processes is imperative, albeit allowing sufficient flexibility to enable them to improve the touchpoints if possible. Equally, customers may wish to co-design touchpoints with suppliers or manage them themselves. Managers must take account of these wishes, but still seek to maintain a level of influence in touchpoint design. Fourth, for mismatches across the customer's journey, managers need to be aware of the complexity in the customer journey. For example, the procurement of a range of different offerings may entail separate customer journeys for each one. Thus, touchpoints need to be carefully developed to take account of this diversity. Finally, managers should be cognizant of the dynamics of customer experiences, given that the type of customer experience required can change over time. Hence managers should ensure they can adapt and switch between relationship modes as necessary and take account of the changing roles of partners in these relationships. Indeed, strong knowledge of the requirements and preferences among key stakeholders within the customer organization should develop over time to ensure that customer expectations match the experiences they are offered.

\subsection{Limitations and further research}

This paper is not without limitations, which are discussed here together with potential avenues for future research. The conceptual nature of the paper, and the limited prior research in this field, means that empirical studies are needed to increase our understanding of both the customer and organizational perspective on customer experience in B2B contexts. In particular, we see a strong need to test the identified challenges of B2B CEM in empirical 
settings. Extant studies on the B2B customer experience and its management raise some interesting questions about how to manage the customer experience where simultaneous and parallel customer journeys involve multiple actors and different durations. These need to be managed either by an in-house service organization, a partner, or the customer. This suggests action research, ethnography, or longitudinal case studies might be beneficial to fully capture this multi-dimensional concept. An alternative method is to use extensive data sets from individual customer journeys to capture critical customer experiences. Opportunities to capture and analyze such complex and parallel data streams are emerging with growth in the use of digital technologies, artificial intelligence and big data.

The infusion of a customer experience perspective in a B2B setting can aid researchers in addressing some fundamental issues of B2B marketing. While relationships are a normative factor in B2B marketing, a customer experience perspective may help to answer the question posed by Hadjikhani and LaPlaca (2013, p. 303): “What is a relationship?" In this regard, customer experiences represent a new "battleground" to re-concetualize and revisit some fundamental B2B marleting concepts. Finally, future research could usefully examine supplier, customer, partner, or external actor capabilities required to develop and manage customer experiences effectively within B2B settings. 


\section{References}

Aarikka-Stenroos, L., \& Jaakkola, E. (2012). Value co-creation in knowledge intensive business services: A dyadic perspective on the joint problem solving process. Industrial Marketing Management, 41(1), 15-26.

Anderson, W. T. (1994). Deciphering dyads: Concepts, methods, and controversies in relational research. Psychology \& Marketing, 11(5), 447-466.

Andersson-Cederholm, E., \& Gyimóthy, S. (2010). The service triad: Modelling dialectic tensions in service encounters. The Service Industries Journal, 30(2), 265-280.

Berry, L. L., Carbone, L. P., \& Haeckel, S. H. (2002). Managing the total customer experience. MIT Sloan Management Review, 43(3), 85-89.

Biggemann, S., Kowalkowski, C., Maley, J., \& Brege, S. (2013). Development and implementation of customer solutions: A study of process dynamics and market shaping. Industrial Marketing Management, 42(7), 1083-1092.

Bitner, M. J. (1990). Evaluating service encounters: The effects of physical surroundings and employee responses. The Journal of Marketing, 54(2), 69-82.

Bolton, R. N., McColl-Kennedy, J. R., Cheung, L., Gallan, A., Orsingher, C., Witell, L., \& Zaki, M. (2018). Customer experience challenges: Bringing together digital, physical and social realms. Journal of Service Management, 29(5), 776-808.

Brady, T., Davies, A., \& Gann, D. M. (2005). Creating value by delivering integrated solutions. International Journal of Project Management, 23(5), 360-365.

Burton, J., Story, V., Zolkiewski, J., Raddats, C., Baines, T. S., \& Medway, D. (2016). Identifying tensions in the servitized value chain: If servitization is to be successful, servitizing firms must address the tensions the process creates in their value network. Research-Technology Management, 59(5), 38-47

Cortez, R. M., \& Johnston, W. J. (2017). The future of B2B marketing theory: A historical 
and prospective analysis. Industrial Marketing Management, 66, 90-102.

Das, T. K., \& Teng, B. S. (1998). Between trust and control: Developing confidence in partner cooperation in alliances. Academy of Management Review, 23(3), 491-512.

Day, G. (2000). Managing market relationships. Journal of the Academy of Marketing Science, 28(1), 28-30.

Eggert, A., Ulaga, W., Frow, P., \& Payne, A. (2018). Conceptualizing and communicating value in business markets: From value in exchange to value in use. Industrial Marketing Management, 69, 80-90.

Forkmann, S., Henneberg, S. C., Witell, L., \& Kindström, D. (2017). Driver configurations for successful service infusion. Journal of Service Research, 20(3), 275-291.

Grewal, D., Levy, M., \& Kumar, V. (2009). Customer experience management in retailing: An organizing framework. Journal of Retailing, 85(1), 1-14.

Gundlach, G. T., \& Murphy, P. E. (1993). Ethical and legal foundations of relational marketing exchanges. The Journal of Marketing, 57(4), 35-46.

Hadjikhani, A., \& LaPlaca, P. (2013). Development of B2B marketing theory. Industrial Marketing Management, 42(3), 294-305.

Håkansson, H., Ford, D., Gadde, L. E., Snehota, I., \& Waluszewski, A. (2009). Business in networks. Chichester, John Wiley \& Sons.

Harby, J. (2018). More than 200 UK shopping centres 'in crisis'. www.bbc.co.uk/news/ukengland-45707529 (Accessed on: 06/11/2018).

Heinonen, K., Strandvik, T., Mickelsson, K., Edvardsson, B., Sundström, E., \& Andersson, P. (2010). A customer-dominant logic of service. Journal of Service Management, 21(4), $531-548$.

Hirschman, E. C., \& Holbrook, M. B. (1982). Hedonic consumption: Emerging concepts, methods and propositions. The Journal of Marketing, 46(3), 92-101. 
Hollyoake, M. (2009). The four pillars: Developing a 'bonded' business-to-business customer experience. Journal of Database Marketing \& Consumer Strategy Management, 16(2), $132-158$.

Holmlund, M. (2004). Analyzing business relationships and distinguishing different interaction levels. Industrial Marketing Management, 33(4), 279-287.

Homburg, C., Jozić, D., \& Kuehnl, C. (2017). Customer experience management: Toward implementing an evolving marketing concept. Journal of the Academy of Marketing Science, 45(3), 377-401.

Johnson, M. D., \& Selnes, F. (2004). Customer portfolio management: Toward a dynamic theory of exchange relationships. Journal of Marketing, 68(2), 1-17.

Kandampully, J., Zhang, T., \& Jaakkola, E. (2018). Customer experience management in hospitality: A literature synthesis, new understanding and research agenda. International Journal of Contemporary Hospitality Management, 30(1), 21-56.

Kowalkowski, C. (2011). Dynamics of value propositions: Insights from service-dominant logic, European Journal of Marketing, 45(1/2), 277-294.

Kowalkowski, C., \& Ulaga, W. (2017). Service strategy in action: A practical guide for growing your B2B service and solution business. Scottsdale: AZ, Service Strategy Press.

Kowalkowski, C., Witell, L., \& Gustafsson, A. (2013). Any way goes: Identifying value constellations for service infusion in SMEs. Industrial Marketing Management, 42(1), $18-30$.

Kranzbühler, A. M., Kleijnen, M. H. P., Morgan, R. E., \& Teerling, M. (2018). The multilevel nature of customer experience research: An integrative review and research agenda. International Journal of Management Reviews, 20(2), 433-456.

Kranzbühler, A. M., Kleijnen, M. H. P., \& Verlegh, P. W. J. (2018). Outsourcing the pain, 
keeping the pleasure: Effects of outsourced touchpoints in the customer journey. Journal of the Academy of Marketing Science, 47(2), 1-20.

Lemke, F., Clark, M., \& Wilson, H. (2011). Customer experience quality: An exploration in business and consumer contexts using repertory grid technique. Journal of the Academy of Marketing Science, 39(6), 846-869.

Lemon, K. N., \& Verhoef, P. C. (2016). Understanding customer experience throughout the customer journey. Journal of Marketing, 80(6), 69-96.

McColl-Kennedy, J. R., Zaki, M., Lemon, K. N., Urmetzer, F., \& Neely, A. (2019). Gaining customer experience insights that matter. Journal of Service Research, 22(1), 8-26.

Meyer, C., \& Schwager, A. (2007). Understanding customer experience. Harvard Business Review, 85(2), 116-126.

Mikolon, S., Kolberg, A., Haumann, T., \& Wieseke, J. (2015). The complex role of complexity: How service providers can mitigate negative effects of perceived service complexity when selling professional services. Journal of Service Research, 18(4), 513528.

Mora Cortez, R., \& Johnson, W. J. (2017). The future of B2B marketing theory: A historical and prospective analysis. Industrial Marketing Management, 66, 90-102.

Murphy, J. A., Burton, J., Gleaves, R., \& Kitshoff, J. (2005). Converting customer value: From retention to profit. USA, John Wiley \& Sons.

Nordin, F., \& Kowalkowski, C. (2010). Solutions offerings: A critical review and reconceptualisation. Journal of Service Management, 21(4), 441-459.

Nordin, F., Brozovic, D., \& Holmlund, M. (2013). Disintermediation in business-to-business service channels: Mechanisms and challenges. Journal of Business-to-Business Marketing, 20(4), 179-192.

Otnes, C. C., Ilhan, B. E., \& Kulkarni, A. (2012). The language of marketplace rituals: 
Implications for customer experience management. Journal of Retailing, 88(3), 367383.

Pansari, A., \& Kumar, V. (2017). Customer engagement: The construct, antecedents, and consequences. Journal of the Academy of Marketing Science, 45(3), 294-311.

Patrício, L., Fisk, R. P., \& Falcão e Cunha, J. (2008). Designing multi-interface service experiences: The service experience blueprint. Journal of Service Research, 10(4), 318334.

Patrício, L., Fisk, R. P., Falcão e Cunha, J., \& Constantine, L. (2011). Multilevel service design: From customer value constellation to service experience blueprinting. Journal of Service Research, 14(2), 180-200.

Pine, B. J., \& Gilmore, J. H. (1998). Welcome to the experience economy. Harvard Business Review, 76, 97-105.

Puccinelli, N. M., Goodstein, R. C., Grewal, D., Price, R., Raghubir, P., \& Stewart, D. (2009). Customer experience management in retailing: Understanding the buying process. Journal of Retailing, 85(1), 15-30.

Raddats, C., Baines, T., Burton, J., Story, V. M., \& Zolkiewski, J. (2016). Motivations for servitization: The impact of product complexity. International Journal of Operations \& Production Management, 36(5), 572-591.

Raddats, C., Zolkiewski, J., Story, V. M., Burton, J., Baines, T., \& Ziaee Bigdeli, A. (2017). Interactively developed capabilities: Evidence from dyadic servitization relationships. International Journal of Operations \& Production Management, 37(3), 382-400.

Rangan, V. K., \& Bowman, G. T. (1992). Beating the commodity magnet. Industrial Marketing Management, 21(3), 215-224.

Reimann, M., Schilke, O., \& Thomas, J. S. (2010). Customer relationship management and firm performance: The mediating role of business strategy. Journal of the Academy of 
Marketing Science, 38(3), 326-346.

Renault, C., Dalsace, F., \& Ulaga, W. (2010). Michelin fleet solutions-From selling tires to selling kilometers. ECCH case study.

Roy, S., Sreejesh, S., \& Bathia, S. (2019). Service quality versus service experience: An empirical examination of the consequential effects in B2B services. Industrial Marketing Management, early view. https://doi.org/10.1016/j.indmarman.2019.02.017.

Sheth, J. N., \& Sharma, A. (2008). The impact of the product to service shift in industrial markets and the evolution of the sales organization. Industrial Marketing Management, $37(3), 260-269$.

Talwar, V., Burton, J., \& Murphy, J. A. (2008). A non-matrix approach to customer relationship portfolio management: A case study from the UK industrial market context. Journal of Customer Behaviour, 7(3), 231-255.

Tuli, K. R., Kohli, A. K., \& Bharadwaj, S. G. (2007). Rethinking customer solutions: From product bundles to relational processes. Journal of Marketing, 71(3), 1-17.

Van Iwaarden, J., \& van der Valk, W. (2013). Controlling outsourced service delivery: Managing service quality in business service triads. Total Quality Management \& Business Excellence, 24(9-10), 1046-1061.

Van Weele, A. J. (2002). Purchasing and supply management: Analysis, planning and practice. London: Thomson Learning.

Verhoef, P. C., Lemon, K. N., Parasuraman, A., Roggeveen, A., Tsiros, M., \& Schlesinger, L. A. (2009). Customer experience creation: Determinants, dynamics and management strategies. Journal of Retailing, 85(1), 31-41.

Voorhees, C. M., Fombelle, P. W., Gregoire, Y., Bone, S., Gustafsson, A., Sousa, R., \& Walkowiak, T. (2017). Service encounters, experiences and the customer journey: Defining the field and a call to expand our lens. Journal of Business Research, 79, 269- 
280.

Webster Jr, F. E., \& Wind, Y. (1972). A general model for understanding organizational buying behavior. Journal of Marketing, 36(2), 12-19.

Wynstra, F., Spring, M., \& Schoenherr, T. (2015). Service triads: A research agenda for buyer-supplier-customer triads in business services. Journal of Operations Management, 35, 1-20.

Zablah, A. R., Johnston, W. J., \& Bellenger, D. N. (2005). Transforming partner relationships through technological innovation. Journal of Business \& Industrial Marketing, 20(7), $355-363$

Zaheer, S., \& Zaheer, A. (2006). Trust across borders. Journal of International Business Studies, 37(1), 21-29.

Zolkiewski, J. (2004). Relationships are not ubiquitous in marketing. European Journal of Marketing, 38(1/2), 24-29.

Zolkiewski, J., Burton, J., \& Stratoudaki, S. (2008). The delicate power balance in advertising agency-client relationships: Partnership or battleground? The case of the Greek advertising market. Journal of Customer Behaviour, 7(4), 315-332.

Zolkiewski, J., \& Turnbull, P. (2002). Do relationship portfolios and networks provide the key to successful relationship management? Journal of Business \& Industrial Marketing, 17(7), 575-597.

Zolkiewski, J., Story, V., Burton, J., Chan, P., Gomes, A., Hunter-Jones, P., O’Malley, L, Peters, L. D., Raddats, C., \& Robinson, W. (2017). Strategic B2B customer experience management: The importance of outcomes-based measures. Journal of Services Marketing, 31(2), 172-184. 
Table 1: Conceptualizations of customer experience management

\begin{tabular}{|c|c|c|c|c|}
\hline Authors & Type of study & Context & Concept & Contribution \\
\hline $\begin{array}{l}\text { Berry, Carbone, \& } \\
\text { Haeckel (2002). }\end{array}$ & Conceptual & $\mathrm{B} 2 \mathrm{C}$ & $\begin{array}{l}\text { Orchestrating the "clues" that people detect } \\
\text { during the buying process. }\end{array}$ & $\begin{array}{l}\text { Specifies a framework for orchestrating functional and } \\
\text { emotional clues that customers use to evaluate their } \\
\text { experience. }\end{array}$ \\
\hline $\begin{array}{l}\text { Grewal, Levy, \& } \\
\text { Kumar (2009) }\end{array}$ & Conceptual & $\begin{array}{l}\mathrm{B} 2 \mathrm{C}, \\
\text { retailing }\end{array}$ & $\begin{array}{l}\text { Ensuring that every shopping experience } \\
\text { occurs consistently and meets and/or } \\
\text { exceeds customers' expectations. }\end{array}$ & $\begin{array}{l}\text { Specifies a framework of macro and firm-controlled } \\
\text { factors that influence the customer experience. }\end{array}$ \\
\hline Puccinelli et al. (2009) & Conceptual & $\begin{array}{l}\mathrm{B} 2 \mathrm{C}, \\
\text { retailing }\end{array}$ & $\begin{array}{l}\text { Using consumer behavior theories to inform } \\
\text { and illuminate customer understanding, } \\
\text { ensure greater predictability, and identify } \\
\text { sustainable retail advantages. }\end{array}$ & $\begin{array}{l}\text { Specifies an organizing framework including theoretical } \\
\text { domains needed to understand the customer experience. }\end{array}$ \\
\hline Verhoef et al. (2009) & Conceptual & $\begin{array}{l}\mathrm{B} 2 \mathrm{C} \text {, } \\
\text { retailing }\end{array}$ & $\begin{array}{l}\text { A strategy to engineer the customer } \\
\text { experience to create value for both the } \\
\text { customer and the firm. }\end{array}$ & $\begin{array}{l}\text { Specifies a framework encompassing drivers of the } \\
\text { customer experience, including social environment, } \\
\text { service interface, retail atmosphere, assortment, price, } \\
\text { retail brand, channels experiences, and previous } \\
\text { experiences. }\end{array}$ \\
\hline $\begin{array}{l}\text { Otnes, Ilhan, \& } \\
\text { Kulkarni (2012) }\end{array}$ & Qualitative & $\begin{array}{l}\mathrm{B} 2 \mathrm{C} \\
\text { retailing }\end{array}$ & $\begin{array}{l}\text { Tailoring marketing strategies to each } \\
\text { experience. }\end{array}$ & $\begin{array}{l}\text { Specifies strategies for the use of language to facilitate } \\
\text { the marketplace ritual. }\end{array}$ \\
\hline $\begin{array}{l}\text { Homburg, Jozic, \& } \\
\text { Kuehnl (2017) }\end{array}$ & Qualitative & $\begin{array}{l}\mathrm{B} 2 \mathrm{C} \\
\text { cross- } \\
\text { sectional }\end{array}$ & $\begin{array}{l}\text { Cultural mindsets, strategic directions, and } \\
\text { firm capabilities for continuous renewal of } \\
\text { customer experiences. }\end{array}$ & $\begin{array}{l}\text { Provides a comprehensive marketing management } \\
\text { concept beyond market orientation and customer } \\
\text { relationship management. }\end{array}$ \\
\hline $\begin{array}{l}\text { Kandampully, Zhang, } \\
\text { \& Jaakkola (2018) }\end{array}$ & Conceptual & $\begin{array}{l}\text { B2C, } \\
\text { hospitality }\end{array}$ & $\begin{array}{l}\text { Collective functions and various activities } \\
\text { within the organization, including strategy, } \\
\text { marketing operations, service design, human } \\
\text { resources, technology, and social media. }\end{array}$ & $\begin{array}{l}\text { Provides a model based on a holistic perspective and } \\
\text { broadly illustrates essential factors for a hospitality firm. }\end{array}$ \\
\hline $\begin{array}{l}\text { Zolkiewski et al. } \\
\text { (2017) }\end{array}$ & Conceptual & $\mathrm{B} 2 \mathrm{~B}$ & $\begin{array}{l}\text { A strategic, dynamic and co-creation- } \\
\text { oriented approach to understanding the B2B } \\
\text { customer experience. }\end{array}$ & $\begin{array}{l}\text { Proposes a strategic customer experience management } \\
\text { framework highlighting measurement of the customer } \\
\text { experience. }\end{array}$ \\
\hline $\begin{array}{l}\text { McColl-Kennedy et al. } \\
(2019)\end{array}$ & Quantitative & $\mathrm{B} 2 \mathrm{~B}$ & $\begin{array}{l}\text { A framework that relates to touchpoints, } \\
\text { value creation elements, discrete emotions, } \\
\text { and cognitive responses. }\end{array}$ & $\begin{array}{l}\text { (1) Taking a customer perspective (2) Identifying root } \\
\text { causes (3) Uncovering at-risk segments (4) Capturing } \\
\text { customers' emotional and cognitive responses (5) } \\
\text { Spotting and preventing diminishing sales (6) } \\
\text { Prioritizing actions to improve CX }\end{array}$ \\
\hline
\end{tabular}


Table 2: Touchpoint control and customer journey stage

\begin{tabular}{|c|c|c|c|c|}
\hline & $\begin{array}{l}\text { Pre-bid engagement } \\
\text { stage }\end{array}$ & $\begin{array}{l}\text { Negotiations } \\
\text { stage }\end{array}$ & Implementation stage & $\begin{array}{l}\text { Operations } \\
\text { stage }\end{array}$ \\
\hline $\begin{array}{l}\text { Supplier } \\
\text { activity }\end{array}$ & $\begin{array}{l}\text { Sales representative } \\
\text { talks to purchasing } \\
\text { department of the } \\
\text { customer firm to } \\
\text { understand the } \\
\text { customer's business } \\
\text { needs }\end{array}$ & $\begin{array}{l}\text { Bid manager } \\
\text { negotiates } \\
\text { contract with } \\
\text { customer firm }\end{array}$ & $\begin{array}{l}\text { Engineering and } \\
\text { software departments } \\
\text { modify the offering to } \\
\text { align with customer's } \\
\text { environment }\end{array}$ & $\begin{array}{l}\text { Maintenance } \\
\text { by supplier's } \\
\text { service } \\
\text { technicians; } \\
\text { customer } \\
\text { accesses online } \\
\text { platform } \\
\text { provided by } \\
\text { supplier firm }\end{array}$ \\
\hline $\begin{array}{l}\text { Partner } \\
\text { activity }\end{array}$ & $\begin{array}{l}\text { Informs supplier about } \\
\text { customers' existing } \\
\text { operations and } \\
\text { business needs }\end{array}$ & $\begin{array}{l}\text { Assists supplier } \\
\text { by providing } \\
\text { information for } \\
\text { the bid }\end{array}$ & $\begin{array}{l}\text { Software partner } \\
\text { assists the supplier } \\
\text { with systems } \\
\text { integration activities }\end{array}$ & $\begin{array}{l}\text { Third-party } \\
\text { training } \\
\text { provided to } \\
\text { employees of } \\
\text { the customer } \\
\text { firm; partner } \\
\text { firm performs } \\
\text { services on the } \\
\text { purchased } \\
\text { equipment }\end{array}$ \\
\hline $\begin{array}{l}\text { Customer } \\
\text { activity }\end{array}$ & $\begin{array}{l}\text { Top management } \\
\text { initiates discussions } \\
\text { about opportunities for } \\
\text { outsourcing }\end{array}$ & $\begin{array}{l}\text { E-procurement } \\
\text { platform; } \\
\text { purchasing } \\
\text { department } \\
\text { defines the } \\
\text { specification and } \\
\text { selects supplier } \\
\text { for negotiation of } \\
\text { terms and } \\
\text { conditions }\end{array}$ & $\begin{array}{l}\text { Customer contacts } \\
\text { supplier to require } \\
\text { modifications to the } \\
\text { service }\end{array}$ & $\begin{array}{l}\text { ERP system; } \\
\text { customer } \\
\text { decides what } \\
\text { information to } \\
\text { disclose } \\
\text { regarding } \\
\text { future needs }\end{array}$ \\
\hline $\begin{array}{l}\text { External } \\
\text { activity } \\
\text { (ecosystem) }\end{array}$ & $\begin{array}{l}\text { Consultant advises the } \\
\text { customer firm on } \\
\text { business, market or } \\
\text { technical requirements; } \\
\text { benchmarking with } \\
\text { market leaders in other } \\
\text { industries }\end{array}$ & $\begin{array}{l}\text { Competing } \\
\text { suppliers provide } \\
\text { the customer with } \\
\text { rival bids }\end{array}$ & $\begin{array}{l}\text { Consultants and } \\
\text { specialist firms } \\
\text { involved in integration } \\
\text { and deployment }\end{array}$ & $\begin{array}{l}\text { Online } \\
\text { marketplaces } \\
\text { for } \\
\text { consumables, } \\
\text { components, } \\
\text { and spare parts }\end{array}$ \\
\hline
\end{tabular}


Table 3: B2B CEM challenges and implications

$\begin{array}{llll}\text { Challenge Description } & \text { Reason } & \text { Empirical illustration } & \text { Implications for CEM }\end{array}$

Mismatches in Suppliers and customers have

business

relationships

(C1) differing views on the nature of the relationship (transactional or relational), resulting in poor customer experiences or lack of profitability for the supplier.

Individual and collective actors in Providing an improved the customer organization have varying views on the value of an offering, depending on their function and job level.

experience (C2)

Mismatches across the customer journey (C3)
Individual and collective actors within the customer organization have varying experiences, depending on the stage of the customer journey.
Suppliers fail to differentiate between different customer segments; customers have excessive expectations of relational customer experience.

Shell simplified the range of solutions and touchpoints for less profitable customers in their portfolio. As a result, these customers realized the value in their experiences was diminishing.

A fleet operator's drivers are unhappy about an insurance company fitting telematics to their customer experience at organizational level may adversely affect the customer experiences of individual staff.

Experiences are unique and subjective, leading to differences in perception between individuals and/or between individuals and functional units. Different organizational entities may be involved at each stage of the journey.
University procurement managers have a positive purchase experience when buying managed print services rather than purchasing printers, as this reduces organizational costs. Users of the managed print services experience this negatively due to inconvenient printer locations, paper shortages, and slow response to faults.
Need to manage expectations

by ensuring greater

transparency and customer education about the value of experiences offered in contracts at different levels,

Need to help customers to engage with their staff to manage cultural change and demonstrate how the improved organizational experience can be leveraged to improve the experience of individual staff members.

Greater attention should be paid to the needs of all actors when procuring supplier offerings. Measures can be put in place to ensure user support will ameliorate any drawbacks of new offerings.

Need to manage data on product use in order to claim value from new contractual 


\begin{tabular}{|c|c|c|c|c|}
\hline $\begin{array}{l}\text { Lack of } \\
\text { touchpoint } \\
\text { control (C4) }\end{array}$ & $\begin{array}{l}\text { A supplier has limited ability to } \\
\text { ensure the desired behavior of } \\
\text { customers and third parties } \\
\text { because, as principal entities, } \\
\text { other organizations can determine } \\
\text { or influence what actors will do. } \\
\text { The supplier uses a third-party } \\
\text { partner as provider to customers, } \\
\text { or the customer controls the } \\
\text { touchpoint. }\end{array}$ & $\begin{array}{l}\text { Potentially a consequence of } \\
\text { powerful customers or } \\
\text { intermediaries, scale of } \\
\text { customer base, remote } \\
\text { geographic location of } \\
\text { customers, or technical skills } \\
\text { of the partner in delivering } \\
\text { complex goods and services. }\end{array}$ & $\begin{array}{l}\text { A truck manufacturer shifts to } \\
\text { selling hours on the road rather than } \\
\text { truck units and requires a partner- } \\
\text { controlled maintenance network to } \\
\text { facilitate this. }\end{array}$ & $\begin{array}{l}\text { agreements; need to protect } \\
\text { such capabilities and manage } \\
\text { and incentivize the partner to } \\
\text { deliver a customer contact and } \\
\text { service experience that creates } \\
\text { value in use. }\end{array}$ \\
\hline $\begin{array}{l}\text { Dynamics of } \\
\text { customer } \\
\text { experiences } \\
\text { (C5) }\end{array}$ & $\begin{array}{l}\text { Over time, customer expectations } \\
\text { and requirements change the } \\
\text { desired form or type of customer } \\
\text { experience, which may influence } \\
\text { the type of relationship, the role } \\
\text { of touchpoint controller, other } \\
\text { actor roles, and the customer } \\
\text { journey. }\end{array}$ & $\begin{array}{l}\text { Changes in customer desire, } \\
\text { resource shortages, process } \\
\text { innovations, or market } \\
\text { changes can all lead to either } \\
\text { incremental or disruptive } \\
\text { evolution of the CE. }\end{array}$ & $\begin{array}{l}\text { As firms servitize, there may be a } \\
\text { shift from transactional models } \\
\text { (possibly via partners) to extensive } \\
\text { contractually agreed service } \\
\text { relationships that require greater } \\
\text { monitoring and interaction. }\end{array}$ & $\begin{array}{l}\text { Firms must consider the impact } \\
\text { of service innovations on the } \\
\text { customer experience over time. } \\
\text { How will CE be managed in } \\
\text { the future? The impact of such } \\
\text { changes must be considered } \\
\text { and monitored from the } \\
\text { customer's perspective. }\end{array}$ \\
\hline
\end{tabular}


Figure 1: B2B CEM dimensions and challenges

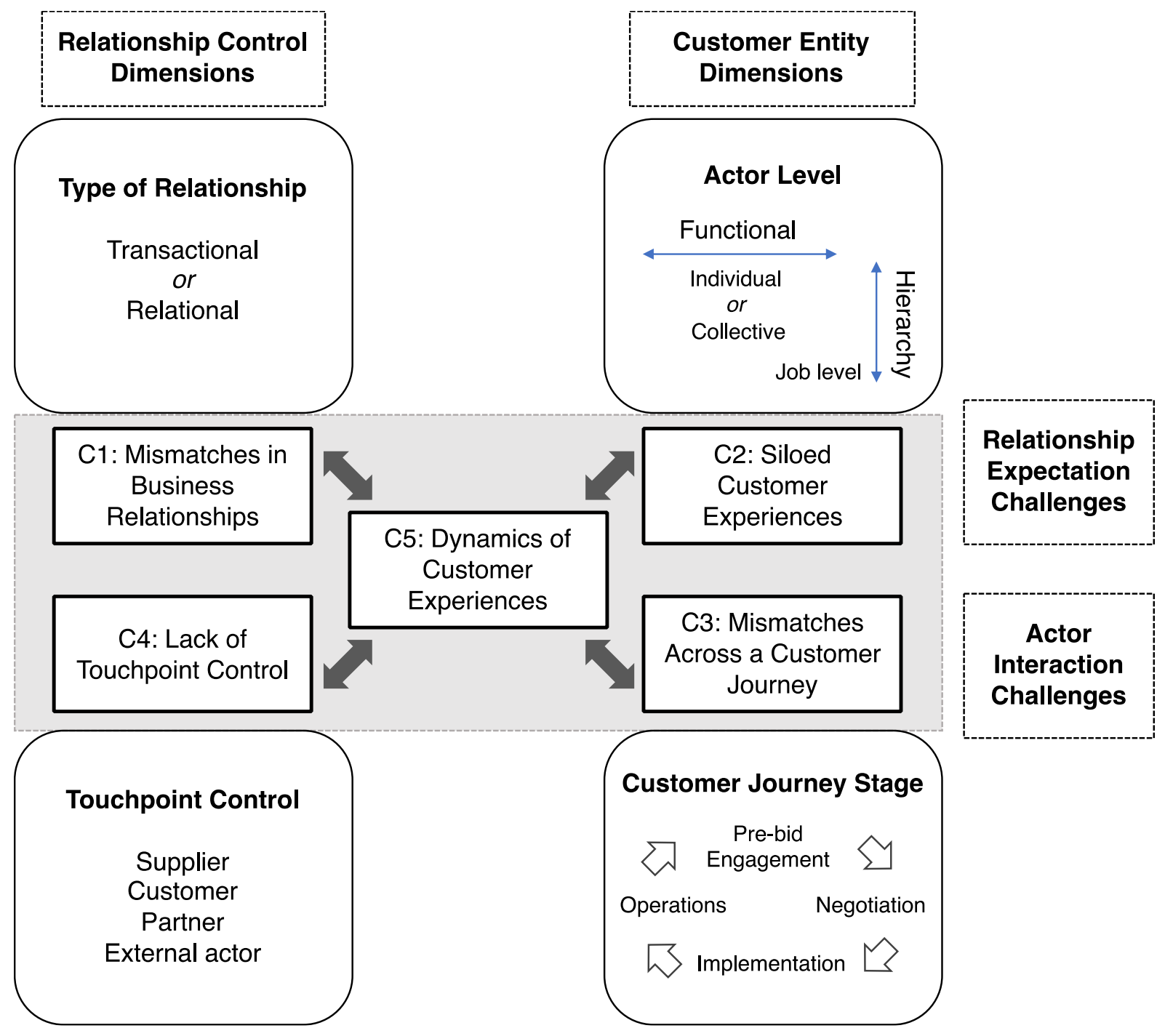

